\title{
The knowledge about diagnostic imaging methods among primary care and medical emergency physicians*
}

\author{
O conhecimento dos médicos da atenção primária à saúde e da urgência sobre os exames de imagem \\ Luciana Mendes Araújo Borém ${ }^{1}$, Maria Fernanda Santos Figueiredo ${ }^{2}$, Marise Fagundes Silveira ${ }^{3}$, \\ João Felício Rodrigues Neto ${ }^{4}$
}

\begin{abstract}
Objective: To evaluate the knowledge about diagnostic imaging methods among primary care and medical emergency physicians. Materials and Methods: Study developed with 119 primary care and medical emergency physicians in Montes Claros, MG, Brazil, by means of a structured questionnaire about general knowledge and indications of imaging methods in common clinical settings. A rate of correct responses corresponding to $\geq 80 \%$ was considered as satisfactory. The Poisson regression (PR) model was utilized in the data analysis. Results: Among the 81 individuals who responded the questionnaire, 65\% ( $n=53$ ) demonstrated to have satisfactory general knowledge and $44 \%(n=36)$ gave correct responses regarding indications of imaging methods. Respectively, 65\% ( $n=53)$ and $51 \%(n=41)$ of the respondents consider that radiography and computed tomography do not use ionizing radiation. The prevalence of a satisfactory general knowledge about imaging methods was associated with medical residency in the respondents' work field (PR $=4.55$; IC 95\%: 1.18-16.67; $p$-value: 0.03), while the prevalence of correct responses regarding indication of imaging methods was associated with the professional practice in primary health care (PR = 1.79; IC 95\%: 1.16-2.70; $p$-value: 0.01). Conclusion: Major deficiencies were observed as regards the knowledge about imaging methods among physicians, with better results obtained by those involved in primary health care and by residents.
\end{abstract}

Keywords: Imaging diagnosis; Radiology; Imaging studies.

Resumo Objetivo: Avaliar o conhecimento de médicos da atenção primária à saúde e da urgência sobre os exames de imagem. Materiais e Métodos: Estudo realizado com 119 médicos, integrantes da atenção primária à saúde e/ou da urgência hospitalar de Montes Claros, MG, por meio de questionário estruturado contendo questões sobre conhecimentos gerais e indicação dos métodos de imagem. Foi considerado satisfatório um acerto $\geq 80 \%$ das questões. Os dados foram analisados pelo modelo de regressão de Poisson (RP). Resultados: Dos 81 indivíduos que responderam ao questionário, 65\% ( $n=53)$ e 44\% $(n=36)$, respectivamente, apresentaram conhecimentos satisfatórios em relação aos conhecimentos gerais e à indicação dos métodos de imagem. Respectivamente, $65 \%(n=53)$ e $51 \%(n=41)$ dos participantes consideram que a radiografia e a tomografia computadorizada não utilizam radiação ionizante. A prevalência de conhecimentos gerais satisfatórios sobre os métodos de imagem apresentou associação com a presença de residência na área de atuação (RP = 4,55; IC 95\%: 1,18-16,67; valor-p: 0,03), enquanto a prevalência da indicação satisfatória dos métodos de imagem apresentou associação com a atuação do profissional na atenção primária à saúde $(R P=1,79$; IC 95\%: 1,16-2,70; valor-p: 0,01). Conclusão: Há deficiências importantes no conhecimento dos médicos em relação aos exames de imagem, com melhores resultados obtidos pelos profissionais da atenção primária à saúde e pelos que possuem residência médica na área de atuação.

Unitermos: Diagnóstico por imagem; Radiologia; Exames médicos.

Borém LMA, Figueiredo MFS, Silveira MF, Rodrigues Neto JF. The knowledge about diagnostic imaging methods among primary care and medical emergency physicians. Radiol Bras. 2013 Nov/Dez;46(6):341-345.

* Study developed at Universidade Estadual de Montes Claros (Unimontes), Montes Claros, MG, Brazil.

1. Master, Fellow PhD degree in Health Sciences, Universidade Estadual de Montes Claros (Unimontes), MD, Radiologist, Santa Casa de Montes Claros, Montes Claros, MG, Brazil.

2. Master, Professor, Nursing Department, Universidade Estadual de Montes Claros (Unimontes), Montes Claros, MG, Brazil.

3. PhD, Biostatistician, Program of Post-graduation in Health Sciences, Department of Exact Sciences, Universidade Estadual de Montes Claros (Unimontes), Montes Claros, MG, Brazil.

4. PhD, Professor, Program of Post-graduation in Health Sciences, Medicine Department, Universidade Estadual de Montes Claros (Unimontes), Montes Claros, MG, Brazil.

\section{INTRODUCTION}

The past decades have witnessed an explosive increase in the quantity and variety of available imaging diagnosis meth-

Mailing Address: Dra. Luciana Mendes Araújo Borém. Radiologia e Diagnóstico por Imagem - Santa Casa de Montes Claros - Setor de Radiologia. Praça Honorato Alves, 22, Centro. Montes Claros, MG, Brazil, 39400-103. E-mail: Imendesab@ hotmail.com.

Received February 27, 2013. Accepted after revision July 22, 2013. ods and services ${ }^{(\mathbf{1})}$, playing a growing role in patients' care and therapeutic decisions making $^{(2,3)}$. Among the factors associated with such increase the following can be mentioned: scientific and technological developments, greater availability and functionality of imaging methods, demand from patients for more exams, and aging, with the consequential increase in clinical complexity of the population ${ }^{(\mathbf{1}, 2)}$. In Brazil, studies have demonstrated an increase in 
number of practically all diagnostic procedures relying on imaging ${ }^{(2,4)}$.

As the utilization of imaging services increases, so does the preoccupation with the appropriate utilization of such resources $^{(\mathbf{1 , 5})}$. Historically, the ordering of complementary exams has been indiscriminately carried out in a non-standardized manner ${ }^{(6)}$. A high proportion of radiological studies is incorrectly requested and obtained $^{(\mathbf{1})}$. Some studies in the literature suggest that, early in this century, such proportion could be between $30 \%$ and $40 \%$ in the United States of America ${ }^{(7)}$. A Brazilian study undertaken in 2005 at a university hospital, indicates strong evidences that requests for chest radiography are made without defined criteria or are influenced by random parameters ${ }^{(\mathbf{5})}$. From the radiologist's point-of-view, inappropriate requests stand out as potential generators of professional conflicts, as such requests must be fulfilled under the penalty of incurring in ethical violations ${ }^{(8)}$.

Because of its guiding principles ${ }^{(\mathbf{1 0})}$, primary health care (PHC), primarily represented by family doctors, has been considered an important way to prevent the indiscriminate utilization of complementary exams ${ }^{(\mathbf{9})}$. Family doctors, among all physicians, are pointed out in the international literature as those who generate the lowest costs with complementary ${ }^{(11)}$. However, studies report that even among such group of physicians, there is frequent and abusive utilization of imaging exams, with little contribution for the clinical management of patients ${ }^{(\mathbf{1 2})}$.

The imaging studies requested at urgent care/emergency services stand out in this context, not only because of the high demand for procedures to fulfill such requests, but also because of the need for immediate definition of the clinical approach to be adopted after the interpretation of such imaging studies ${ }^{(\mathbf{9 , 1 3})}$. According to Cavalcanti et al. ${ }^{(13)}$, approximately $50 \%$ of the patients who seek assistance at emergency services, are submitted to some radiological exam.

Educational measures stand out among the measures tested with the purpose of improving medical behavior in relation to the ordering of imaging exams ${ }^{(\mathbf{1 4}, 15)}$. According to Taha ${ }^{(3)}$, the education in radiodiagnosis has been undergoing significant changes over the past years, due to the constant developments of imaging methods and the sharp increase in their applications.

The present study is aimed at assessing the general knowledge on imaging methods and their indications by PHC and medical emergency physicians.

\section{MATERIALS AND METHODS}

The present research was approved by the Committee for Ethics in Research of Universidade Estadual de Montes Claros (Unimontes) under number 2963/2011.

This cross-sectional and quantitative study was undertaken with all the urban teams involved in the family health strategy and those teams working in hospital emergency network in the municipality of Montes Claros, MG, Brazil, in the period between November 2011 and January 2012. The inclusion criteria were the following: to be a physician, working at the selected services for at least six months (period considered as the minimum required for adaptation), and acceptance to participate in the study by means of execution of a term of free and informed consent. Those professionals with less than six months at the services and those who refused to participate in the study were excluded.

The study was based on a structured questionnaire, based on international curricular guidelines for the teaching of radiology, which list the minimum necessary learning subjects for each professional area, in the context of medical education $^{(16,17)}$. The variables comprised by the questionnaire are listed below:

- Sociodemographic variables: gender, age, marital status, race, religion.

- Variables regarding professional education: graduation university, specialization, work field (PHC and/or emergency), medical residency, medical residency in the area of specialization (PHC and/or emergency), proof of title of medical society, proof of title of medical society in the area of specialization (PHC and/or emergency), master's degree, $\mathrm{PhD}$ degree, time elapsed since the medicine course completion.

- Variables regarding professional experience: work field (PHC and/or emergency); time of work in that field; time of employment; work at a different care level other than that where the professional was approached.

- Variables regarding professional education: participation in learning strategies; classes; lectures; courses; congresses; study-groups; specialization; stricto sensu post-graduation; seminars; and participation in the PHC continued education programs.

- Variables regarding general knowledge on imaging methods: which methods utilize ionizing radiation; which methods may require the utilization of intravenous contrast media, which methods more commonly cause claustrophobia; which methods should be avoided in patients with metal implants; and magnitude of costs of the different imaging methods

- Variables regarding correct indication of imaging studies in common clinical situations at PHC (pneumonia, initial evaluation of pelvic pain in women, headaches, cholecystitis, diverticulitis) or in emergencies (pneumothorax, pneumoperitoneum, aortic dissection, intracranial hematoma, stroke, testicular torsion, acute cholecystitis, acute diverticulitis, proximal femur fracture).

It is necessary to clarify that the term "work field" was utilized to refer to the level of medical attention where the professional was approached. Thus, medical residency and/or specialization in the work field refer to post-graduation specifically in family and community health and/or in emergency medicine. Therefore, the professional with medical residency in general surgery who works in an emergency service was classified as a resident specialist, but not as a resident in his current work field, in the event that such professional does not hold a title in emergency medicine.

The data were collected by two health field researchers (a master fellow and a $\mathrm{PhD}$ fellow), after a pilot test for training the team and identifying the questions whose understanding might be difficult. The need to change the wording in five of the questions was identified as they were not clearly understood. The professionals were approached in their workplaces, and the questionnaires were applied either as an interview or were filled-out by the respondents themselves and later returned, in accordance with their convenience. 
The answers which were considered correct were so defined by consensus between three radiologists with expertise in the fields of the study. The coefficient of agreement was $100 \%$. The descriptive analysis was based on absolute and relative frequencies, following the categorization of the answers correctness into satisfactory knowledge $(\geq 80 \%)$ or non-satisfactory knowledge $(<80 \%)$. The multiple Poisson regression model was utilized for the calculation of the correctness prevalence ratios. Initially, a bivariate analysis was undertaken, and those variables which presented descriptive levels ( $p$-value of the hypothesis test) of up to $25 \%$ were selected for multiple analysis. The level of statistical significance considered for the multiple model was $p<0.05$ and the confidence interval was $95 \%$. The whole statistical analysis was carried out with the SPSS for Windows 18.0.

\section{RESULTS}

The study population comprised 119 physicians, 57 of them working in PHC and 62 working in emergency units. Twenty participants $(17 \%)$ were excluded as they had been working in the investigated fields for less than six months $(\mathrm{PHC}=6$; emergency care $=14)$. The refusal rate was $15 \%$ $(n=18 ;$ PHC $=9$, emergency care $=9)$, so the final number of professionals who filledout the questionnaires was $81,52 \%(n=42)$ of them involved in PHC and $48 \%(n=39)$ working in hospital emergency care units. Most of the participants were men (59\%; $n=48)$, less than 40 years old $(74 \% ; n=58)$, graduated from public institutions $(63 \% ; n$ =51). As regards post-graduation, most of the population does not hold either a medical residency or specialization title of any type $(53 \% ; n=42$ and $58 \% ; n=46$, respectively) or in their working field $(74 \% ; n=$ 60 and $90 \% ; n=71$, respectively).

While most participants $(n=53 ; 65 \%)$ demonstrated satisfactory general knowledge on imaging methods, the same was not true in relation to the correct indications for such imaging methods in common clinical situations where a frequency of $44 \%(n=36)$ of answers correctness considered as satisfactory. A significant proportion of the studied professionals consider that radiography $(n=53 ; 65 \%)$ and computed tomography $(\mathrm{CT})(n=41 ; 51 \%)$ do not utilize ion- izing radiation, while $43 \%(n=35)$ and $42 \%$ $(n=34)$ consider that ultrasonography (US) and magnetic resonance imaging (MRI) do utilize ionizing radiation. Additionally, $16 \%(n=13)$ of the respondents were not able to correctly order radiography, US, CT and MRI with respect to their costs.

The prevalence of satisfactory general knowledge on imaging methods presented association, in the multiple model, with the presence of medical residency in the working field, with other variables controlled, with a $p$ value of $0.03(\mathrm{PR}=4.55$; CI 95\%: 1.18-16.67) (Table 1).

The prevalence of satisfactory indication for the imaging methods presented positive association, in the multiple model, with professional involved in $\mathrm{PHC}$, with other variables controlled, with a $p$ value of 0.01 $(\mathrm{PR}=1.79$; CI 95\%: 1,16-2.70) (Table 2).

\section{DISCUSSION}

The profile of the professionals included in the study population demonstrates a majority of physicians with less than 40 years of age, less than 10 years after graduation and without medical residency in their work field, in agreement with previous studies. A study evaluating the profile of PHC physicians in the state of São Paulo ${ }^{(\mathbf{1 8})}$ has found a percentage of $44 \%$ of professionals with up to 35 years of age, with $42 \%$ of those with less than five-year experience after graduation, and $73 \%$ without medical residency.

The appropriate request for complementary exams is essential for quality medical assistance with appropriate cost/effectiveness ratio ${ }^{(11)}$. The inappropriate utilization of diagnostic imaging methods has important implications to patients' care $^{(\mathbf{1 9})}$, such as unnecessary risks for allergic reaction to contrast medium, post-biopsy hemorrhages and exposure to ionizing radiation ${ }^{(\mathbf{5 , 9 , 2 0})}$. One should also emphasize the possibility of delaying proper diagnosis and/or therapy $^{(\mathbf{1 9})}$ or even misdiagnosis, as every imaging method presents varied rates of false positive and false negative results $\mathbf{s}^{(\mathbf{9 , 2 0})}$.

More than half the interviewed professionals did not present appropriate knowledge on the correct indication for the imaging methods in common clinical situations, in agreement with previous studies, which demonstrates a high percentage of incorrectly requested radiological studies $^{(\mathbf{1 , 7})}$. In spite of being relatively high, the

Table 1 Bivariate analysis - variables associated with general knowledge on imaging methods.

\begin{tabular}{|c|c|c|c|c|c|c|c|c|}
\hline \multirow[b]{3}{*}{ Variables } & & & \multicolumn{4}{|c|}{ Satisfactory knowledge } & \multirow[b]{3}{*}{$\mathrm{PR}(\mathrm{Cl} 95 \%)$} & \multirow[b]{3}{*}{$p$-value } \\
\hline & \multicolumn{2}{|c|}{ Total } & \multicolumn{2}{|c|}{ Yes } & \multicolumn{2}{|c|}{ No } & & \\
\hline & $n$ & $\%$ & $n$ & $\%$ & $n$ & $\%$ & & \\
\hline \multicolumn{9}{|l|}{ Gender } \\
\hline Female & 33 & 41 & 28 & 53 & 20 & 72 & $1.72(0.86-3.43)$ & \multirow{2}{*}{0.12} \\
\hline Male & 48 & 59 & 25 & 47 & 8 & 28 & 1.00 & \\
\hline \multicolumn{9}{|l|}{ Specialization in the field } \\
\hline Yes & 8 & $10 *$ & 7 & $14^{*}$ & 1 & $4 *$ & $2.94(0.46-1.89)$ & \multirow{2}{*}{0.25} \\
\hline No & 71 & $90 *$ & 45 & $86^{*}$ & 26 & $96^{*}$ & 1.00 & \\
\hline \multicolumn{9}{|l|}{ Residency field } \\
\hline Yes & 21 & 26 & 19 & 36 & 2 & 7 & 4.55 (1.18-16.67) & \multirow{2}{*}{0.03} \\
\hline No & 60 & 74 & 34 & 64 & 26 & 93 & 1.00 & \\
\hline \multicolumn{9}{|l|}{ Work field } \\
\hline $\mathrm{PHC}$ & 42 & 52 & 41 & 77 & 1 & 4 & $29.41(4.15-200.00)$ & \multirow{2}{*}{0.00} \\
\hline Medical emergency & 39 & 48 & 12 & 23 & 27 & 96 & 1.00 & \\
\hline \multicolumn{9}{|l|}{ Time in the service } \\
\hline$<5$ years & 55 & $69 *$ & 38 & 73 & 17 & 61 & $1.42(0.79-2.58)$ & \multirow{2}{*}{0.24} \\
\hline$\geq 5$ years & 25 & $31 *$ & 14 & 27 & 11 & 39 & 1.00 & \\
\hline \multicolumn{9}{|l|}{ Other level of care } \\
\hline Does not act & 56 & 70 & 30 & 58 & 26 & 93 & 5.59 (1.43-21.74) & \multirow{2}{*}{0.01} \\
\hline Acts & 24 & 30 & 22 & 42 & 2 & 7 & 1.00 & \\
\hline \multicolumn{9}{|l|}{ Congresses } \\
\hline Does not participate & 32 & $40 *$ & 18 & $35 *$ & 14 & 50 & $1.50(0.83-2.71)$ & \multirow{2}{*}{0.18} \\
\hline Participates & 48 & $60 *$ & 34 & $65^{*}$ & 14 & 50 & 1.00 & \\
\hline
\end{tabular}

* The totals vary as a function of information losses or lack of responses by the interviewee. 
Table 2 Bivariate analysis - variables associated to correct indication of imaging methods.

\begin{tabular}{|c|c|c|c|c|c|c|c|c|}
\hline \multirow[b]{3}{*}{ Variables } & & & \multicolumn{4}{|c|}{ Satisfactory indication } & \multirow[b]{3}{*}{ PR (Cl 95\%) } & \multirow[b]{3}{*}{$p$-value } \\
\hline & \multicolumn{2}{|c|}{ Total } & \multicolumn{2}{|c|}{ Yes } & \multicolumn{2}{|c|}{ No } & & \\
\hline & $n$ & $\%$ & $n$ & $\%$ & $n$ & $\%$ & & \\
\hline \multicolumn{9}{|l|}{ Specialization in the field } \\
\hline Yes & 46 & $57^{*}$ & 24 & 67 & 22 & $50 *$ & $1.35(0.92-2.00)$ & \multirow{2}{*}{0.13} \\
\hline No & 34 & $43^{*}$ & 12 & 33 & 22 & $50 *$ & 1.00 & \\
\hline \multicolumn{9}{|l|}{ Residency field } \\
\hline Yes & 21 & 26 & 13 & 36 & 8 & 18 & $1.62(0.91-2.86)$ & \multirow{2}{*}{0.10} \\
\hline No & 60 & 74 & 23 & 64 & 37 & $82^{*}$ & 1.00 & \\
\hline \multicolumn{9}{|l|}{ Work field } \\
\hline $\mathrm{PHC}$ & 42 & 52 & 25 & 69 & 17 & 38 & $1.79(1.16-2.20)$ & \multirow[b]{2}{*}{0.031} \\
\hline Medical emergency & 39 & 48 & 11 & 31 & 28 & 62 & 1.00 & \\
\hline \multicolumn{9}{|l|}{ Time in the service } \\
\hline$<5$ years & 25 & $31 *$ & 14 & 39 & 11 & $25^{*}$ & $1.36(0.83-2.23)$ & \multirow[b]{2}{*}{0.22} \\
\hline$\geq 5$ years & 55 & $69 *$ & 22 & 61 & 33 & $75^{*}$ & 1.00 & \\
\hline \multicolumn{9}{|l|}{ Other level of care } \\
\hline Does not act & 56 & 70 & 22 & 61 & 10 & $23^{*}$ & $1.45(0.87-2.44)$ & \multirow{2}{*}{0.15} \\
\hline Acts & 24 & 30 & 14 & 39 & 34 & $77^{*}$ & 1.00 & \\
\hline \multicolumn{9}{|l|}{ Courses } \\
\hline Does not participate & 35 & $44^{*}$ & 12 & $34 *$ & 23 & $51^{*}$ & $1.34(0.92-1.97)$ & \multirow[b]{2}{*}{0.13} \\
\hline Participates & 45 & $56^{*}$ & 23 & $66^{*}$ & 22 & $49 *$ & 1.00 & \\
\hline \multicolumn{9}{|l|}{ Lecturers } \\
\hline Does not participate & 5 & $6^{*}$ & 1 & $3^{*}$ & 4 & $9 *$ & $1.46(0.90-2.38)$ & \multirow{2}{*}{0.12} \\
\hline Participates & 75 & $94 *$ & 34 & $97 *$ & 41 & $91^{*}$ & 1.00 & \\
\hline
\end{tabular}

* The totals vary as a function of information losses or Lack of response by the interviewee.

cutoff point of $80 \%$ utilized in the present study was defined as the questions were considered as being related to basic level subjects $^{(16,17)}$ and for the importance of correctly indicating exams with considerable costs and risks. Considering that the radiologist most of times does not have enough clinical data to contest the indication of an exam, the ethical conflict described by Scatigno Neto ${ }^{(\mathbf{8})}$ would in fact manifest, as the radiologist would be performing a high number of inappropriately indicated studies.

Currently, considerable attention has been dedicated to the high costs of medical assistance and the need for attaining savings in the utilization of resources ${ }^{(15,20)}$. The imaging methods stand out in the costs generated by diagnostic methods to the health system ${ }^{(\mathbf{1}, \mathbf{8}, \mathbf{1 5}, \mathbf{1 9})}$. Thus, in spite of being relatively low, the percentage of $16.25 \%$ of failure by the investigated professionals in correctly requesting radiography, US, CT and MRI in relation to their costs, deserves to be considered, as it effectively compromises the cost/benefit ratio evaluation at the moment such exams are indicated.

As the control of ionizing radiation determined by imaging diagnosis methods becomes increasingly imperative with the ALARA (As Low As Reasonably Achievable) principles being introduced as guidelines for exam protocols ${ }^{(21)}$, it should be considered as truly alarming the fact that most of the investigated professionals believe that radiography and CT do not utilize ionizing radiation, while a significant percentage of those professionals believe that US and MRI do. Such findings demonstrate a clear deficiency in the education of the professionals included in the present study, who increasingly request exams whose basic principles are unknown by most of them. In Brazil, the training in radiology and imaging diagnosis is not mandatory in medical schools, a fact which can lead to wide variation and heterogeneity of curricula, providing, according to many authors, less than would be necessary ${ }^{(22)}$.

The two work fields (primary health care and emergency care) have in common the fact of frequently being the physicians' entrance door to the professional market, reflecting in that sense the knowledge and abilities acquired in their graduation courses. According to some authors ${ }^{(23)}$, $\mathrm{PHC}$ is seen as an option to directly enter the labor market, either as a definitive alternative or simply as a way of accumulat- ing some money before making an option for a specialty. Cabana et al. ${ }^{(24)}$ share such an opinion as regards emergency units, and add that such services have the largest concentration of young physicians among all sectors of the studied hospital, with professionals with less graduation time and less time working in the institution.

After graduation, the physicians' professional education occurs mainly by means of medical residency programs. According to Nunes ${ }^{(25)}$, medical residency is recognized as the best way to introduce physicians to the professional life and also to capacitate such professionals in a given specialty. The findings of the present study reinforce that point-of-view, as the probability of professionals with medical residency in the work field presenting satisfactory general knowledge on imaging methods is 4.55 times that of professionals without such background, with the other variables controlled. It is therefore possible to infer that there are deficiencies in the education in radiology in medical graduation courses, which are addressed, at least partially, by medical residency programs. As regards the studied work fields, it has been observed that the graduated professionals' profile is not sufficiently appropriate to work in PHC and medical emergency, reinforcing the need for supplementation of the education of such professionals ${ }^{(\mathbf{2 6 , 2 7 )}}$. It is important to highlight, however, that among the difficulties faced by such services, are those of hiring skilled professionals to fill available positions and the high turnover of the professionals working in such services ${ }^{(\mathbf{2 6})}$.

The authors of the present study observed a greater number of PHC professionals with medical residency in their working field in relation to the medical emergency professionals with only one individual with medical residency in the field. According to Oliveira ${ }^{(28)}$, there is currently a healthy period of rapid expansion of medical residency programs in PHC. However, among the medical emergency professionals, the reality is quite different. Medical emergency is considered by Conselho Federal de Medicina (Federal Medicine Council) as being a work field and not a medical specialty ${ }^{(29)}$. In spite of the fact that some authors recognize the ineffectiveness of the model where "the physician who does shifts in the emergency 
service over a transitional period in his life", reinforcing the need of investment in the education of specialists in the field, there were, in 2010, only three Brazilian states with programs of medical residency in medical emergency, even without recognition of the specialty programs ${ }^{(27)}$. The discrepancy in the professional education between PHC and medical emergency physicians is reflected on the results of the present study, which demonstrated the superiority in the performance of the PHC professionals, with a probability of presenting satisfactory indices of correct indication of imaging exams 1.82 times that of the medical emergency professionals, with the other variables controlled.

In such a context, which the radiologists' role would be? Cavalcanti et al. ${ }^{(13)}$ report the need for a strong integration of the radiologist with the different specialties involved in an urgent care/emergency service, with a rapid and accurate flow of information between the parties and with active participation of the radiologist in the decision making which determine the therapeutic approaches. Similarly, Scatigno Neto $^{(8)}$ asserts that radiology and imaging diagnosis specialists should also play an active role in primary health care, by means of multi-disciplinary meetings with the other medical specialties, discussing and divulging new diagnostic methods, thus providing other specialists with the knowledge and indications on the best method for each clinical situation.

It is interesting to highlight the difficulties in approaching medical professionals as well as obtaining their acceptance as they are the target study population. The authors believe that the assurance of answers anonymity and the utilization of self-applicable questionnaires facilitated the process, besides the fact that most contacts were carried out by a colleague. One possible bias should be pointed-out, with basis on the fact some professionals filled-out the questionnaires in their work places, while others did it outside such environment, perhaps with more time and with the possibility of resorting to theoretical references.

Due to the cross-sectional nature of the present study, it is not possible to determine a cause-effect relationship between the investigated variables, so the results should be cautiously interpreted.

\section{CONCLUSIONS}

The present results demonstrate relevant knowledge deficiencies among PHC and medical emergency physicians in what concerns correct indications of imaging exams and their basic knowledge on such methods. Better results were obtained among the PHC professionals as compared with the medical emergency professionals, and among those with medical residency in their work fields. However, the data do not support the establishment of a causal relationship among such factors.

\section{REFERENCES}

1. Georgiou A, Prgomet M, Markewycz A, et al. The impact of computerized provider order entry systems on medical-imaging services: a systematic review. J Am Med Inform Assoc. 2011;18:33540.

2. Boéchat AL, Sousa EG, Moreira FA, et al. Proposta de um programa básico para formação do médico residente em radiologia e diagnóstico por imagem. Radiol Bras. 2007;40;33-7.

3. Taha O. Perspectivas para o ensino em radiologia. Radiol Bras. 2008;41(1):vii-viii.

4. Freitas MB, Yoshimura EM. Levantamento da distribuição de equipamentos de diagnóstico por imagem e freqüência de exames radiológicos no Estado de São Paulo. Radiol Bras. 2005;38:34754

5. Ney-Oliveira F, Silvany Neto AM, Santos MB, et al. Relação entre a qualidade do exame clínico e o acerto na requisição da radiografia de tórax. Radiol Bras. 2005;38:187-93.

6. Mathias LA, Guarantini AA, Gozzani JL, et al. Preoperative exams: a critical analysis. Rev Bras Anestesiol. 2006;56:658-68.

7. Dehn TG, O'Connell B, Hall RN, et al. Appropriateness of imaging examinations: current state and future approaches. Imaging Economics. March/April 2000.

8. Scatigno Neto A. A radiologia, o radiologista e as demais especialidades. Radiol Bras. 2005;38(2): iii.

9. Capilheira MF, Santos IS. Epidemiologia da solicitação de exame complementar em consultas médicas. Rev Saúde Pública. 2006;40:289-97.

10. Starfield B. Primary care: concept, evaluation, and policy. New York: Oxford University Press; 1992.

11. Sood R, Sood A, Ghosh AK. Non-evidence-based variables affecting physicians' test-ordering tendencies: a systematic review. Neth J Med. 2007; 65:167-77.

12. Eccles M, Steen N, Grimshaw J, et al. Effect of audit and feedback, and reminder messages on primary-care radiology referrals: a randomised trial. Lancet. 2001;357:1406-9.

13. Cavalcanti AF, Menezes MR. Radiologia de emergência: perspectivas. Radiol Bras. 2001;34(2):vvi.

14. Lee TH, Pearson SD, Johnson PA, et al. Failure of information as an intervention to modify clinical management. A time-series trial in patients with acute chest pain. Ann Intern Med. 1995;122: 434-7.

15. Vartanians VM, Sistrom CL, Weilburg JB, et al. Increasing the appropriateness of outpatient imaging: effects of a barrier to ordering low-yield examinations. Radiology. 2010;255:842-9.

16. Lewia P, Shaffer K. Alliance of Medical Student Educators in Radiology (AMSER). National Medical Student Curriculum in Radiology. [acessado em 17 de janeiro de 2012]. Disponível em: http:// www.aur.org/amser/AMSER_curriculum.html.

17. Royal College of Radiologists. Radiology for Medical Students 4. The place of clinical radiology and imaging in medical student education: recommended framework for curriculum design. [acessado em 17 de janeiro de 2012]. Disponível em: http://www.rcr.ac.uk/docs/radiology/pdf/ medicalstudenttpaper4.pdf.

18. Lopes EZ, Bousquat AEM. Fixação de enfermeiras e médicos na estratégia saúde da família, município de Praia Grande, São Paulo, Brasil. Rev Bras Med Fam Comun. 2011;6:118-24.

19. Roshanov PS, You JJ, Dhaliwal J, et al. Can computerized clinical decision support systems improve practitioners' diagnostic test ordering behavior? A decision-maker-researcher partnership systematic review. Implement Sci. 2011;6:88.

20. Kloetzel K. O diagnóstico clínico: estratégias e táticas. In: Duncan BB, Schmidt MI, Giugliani ERJ, et al. Medicina ambulatorial: condutas de atenção primária baseadas em evidências. $3^{\mathrm{a}} \mathrm{ed}$. Porto Alegre: Artmed; 2004. p. 131-42.

21. Dalmazo J, Elias Jr JE, Brocchi MAC, et al. Otimização da dose em exames de rotina em tomografia computadorizada: estudo de viabilidade em um hospital universitário. Radiol Bras. 2010;43: 241-8.

22. Silva VMC, Luiz RR, Barreto MM, et al. Competence of senior medical students in diagnosing tuberculosis based on chest X-rays. J Bras Pneumol. 2010;36:190-6.

23. Mello GA, Mattos ATR, Souto BGA, et al. Médico de família: ser ou não ser? Dilemas envolvidos na escolha desta carreira. Rev Bras Educ Méd. 2009;33:464-71.

24. Cabana MCFL, Ludermir AB, Silva ER, et al. Transtornos mentais comuns em médicos e seu cotidiano de trabalho. J Bras Psiquiatr. 2007;56: 33-40.

25. Nunes MPT. Residência médica no Brasil - situação atual e perspectivas. Cadernos ABEM. 2004; $1: 30-2$.

26. Gil CRR. Formação de recursos humanos em saúde da família: paradoxos e perspectivas. Cad Saúde Pública. 2005;21:490-8.

27. Piva JP, Borges LAA. Todo paciente em situação de emergência tem direito a ser atendido por um médico emergencista. Rev AMRIGS. 2010;54: 261-2.

28. Oliveira FA. Residência médica e produção de conhecimento [carta ao editor]. R Bras Med Fam Comum. 2010;5:6-8.

29. Conselho Federal de Medicina. Resolução CFM No 1.973/2011. Diário Oficial da União. Brasília, $1^{\circ}$ de agosto de 2011; Seção I, p. 144-147. [acessado em 30 de agosto de 2012]. Disponível em: http://www.portalmedico.org.br/resolucoes/ CFM/2011/1973_2011.htm. 